WiOletTa KILAR

Uniwersytet Pedagogiczny im. Komisji Edukacji Narodowej w Krakowie

\title{
Zróżnicowanie potencjału ekonomicznego światowych korporacji informatycznych
}

W złożonym procesie transformacji przemysłowych układów przestrzennych istotną rolę spełniają korporacje ponadnarodowe, będące przedsiębiorstwami największymi i najbardziej ekspansywnymi, które wpływają na organizowanie światowej przestrzeni gospodarczej, społecznej i kulturowej poprzez różne systemy sieciowych powiązań przestrzenno-produkcyjnych.

Korporacje, jako podmioty konkurujące na rynku światowym oraz inwestujące w wielu krajach, dostosowują swą politykę do globalnych przemian technologicznych i ekonomicznych. Najważniejszym czynnikiem w tym działaniu jest tworzenie, stosowanie i pomnażanie wiedzy, a tendencje w tym zakresie oddziałują na lokowanie przez korporacje ponadnarodowe inwestycji bezpośrednich, działalność filii zagranicznych oraz na gospodarki goszczących je krajów (Zorska 2007). W przestrzeni światowej w wyniku nasilającego się procesu koncentracji kapitału korporacje odznaczają się coraz większym potencjałem ekonomicznym, który niekiedy znacznie przewyższa potencjał gospodarczy wielu krajów. Korporacje światowe poszukują nowych miejsc efektywnej lokalizacji i często w zasadniczym stopniu dyktują warunki funkcjonowania firm na terenie poszczególnych krajów i regionów (Zioło 2009, s. 12-13).

W rankingu The Global $2000^{1}$ z 2008 roku, uwzględniono dwa tysiące największych światowych korporacji, które zostały zaklasyfikowane do 27 różnych branż. Firmy informatyczne obejmowały 130 korporacji, tj. 6,5\% ogółu firm w rankingu, zostały przyporządkowane do 3 branż: półprzewodniki, oprogramowanie i usługi oraz technologie sprzętowe i wyposażenie.

W świetle przedstawionych przesłanek w niniejszych rozważaniach podjęta zostanie analiza potencjału ekonomicznego wyróżnionych korporacji informatycznych. Zmierzać będę do określenia zróżnicowania ich potencjału ekonomicznego w świetle wielu cech, takich jak wartość sprzedaży, wartość zysków/strat, wartość aktywów, wartość rynkowa korporacji informatycznych oraz relacji zachodzących między nimi, a także do określenia ich rankingu w świetle miernika syntetycznego. Przyjęto, że lokalizacje zarządów korporacji informatycznych i ich potencjał ekonomiczny jest jednym z podstawowych kryteriów określających stopień zaawansowania procesów kształtowania społeczeństwa informacyjnego.

Przyjęte mierniki odzwierciedlają potencjał ekonomiczny korporacji. W celu wyróżnienia korporacji o różnym potencjale przeprowadzono analizę wielomiernikową potencjału,

\footnotetext{
1 Magazyn Forbes.
} 
uwzględniającą zróżnicowanie poszczególnych cech, ich wzajemne relacje oraz miernik syntetyczny. Wielomiernikowa analiza wpływa na wzajemne uzupełnianie się poszczególnych mierników i daje wszechstronny obraz potencjału ekonomicznego badanych korporacji. Natomiast miernik syntetyczny opiera się na dużej agregacji mierników empirycznych i ma charakter ogólny (Zioło 1972, 1973, Opałło 1972).

Podstawową rolę w strukturze korporacji odgrywa kapitał, wyrażony m.in. wartością rynkową korporacji, wartością majątku, wielkością zysku czy wielkością kapitału obrotowego. Wartość kapitału określa pozycję korporacji w gospodarce światowej, krajowej czy regionalnej. Zasoby kapitałowe pozwalają bowiem na podejmowanie różnych działań związanych np. z kierunkami prac inwestycyjnych, zakupami czy przejęciami innych firm, zmianami działalności produkcyjnej czy usługowej, podnoszeniem jakości kadry pracowniczej i in. (Zioło 2009, s. 14).

Wyróżnione korporacje informatyczne obejmowały 130 firm charakteryzujących się znacznym potencjałem ekonomicznym, który określa łączna wartość sprzedaży (sales) wynosząca 2015,2 mld USD, tj. 6,8\% udziału w ogóle wartości sprzedaży największych korporacji światowych. Nadto osiagnęły one 6,5\% (152,4 mld USD) ogólnego zysku (profits), ich aktywa (assets) stanowią 1,8\% (2100,4 mld USD) wartości aktywów 2000 największych korporacji. Korporacje informatyczne obejmują 8,1\% (3114,9 mld USD) udziału w wartości rynkowej największych firm.

Badane korporacje cechują się dużym zróżnicowaniem pod względem okresu ich powstania. Najstarszą z analizowanych jest powstała w 1851 roku korporacja Corning, zajmująca się produkcją szkła i ceramiki (lider w produkcji: szklanych substratów do produkcji monitorów LCD, światłowodów, szkła wykorzystywanego w optyce), najmłodszą Tyco Electronics, założono w 2007 roku, będąca dostawcą komponentów elektronicznych, rozwiązań sieciowych, podwodnych systemów telekomunikacyjnych i systemów bezprzewodowych dla klientów w ponad 150 krajach.

Tab. 1. Korporacje informatyczne wg roku powstania

\begin{tabular}{|l|c|c|}
\hline Rok powstania korporacji & Liczba firm & $\begin{array}{c}\text { Struktura } \\
\text { w\% }\end{array}$ \\
\hline przed 1900 rokiem & 9 & 6,9 \\
\hline $1901-1930$ & 8 & 6,2 \\
\hline $1931-1945$ & 13 & 10,0 \\
\hline $1946-1955$ & 4 & 3,1 \\
\hline $1956-1965$ & 8 & 6,2 \\
\hline $1966-1975$ & 15 & 11,5 \\
\hline $1976-1985$ & 37 & 28,5 \\
\hline $1986-1995$ & 19 & 14,6 \\
\hline $1996-2008$ & 17 & 13,1 \\
\hline Suma & 130 & 100,0 \\
\hline
\end{tabular}

Źródło: obliczenia własne na podstawie The Global 2000 z 2008 
Tab. 2. Zróżnicowanie korporacji

\begin{tabular}{|c|c|c|c|c|c|c|}
\hline \multirow[b]{2}{*}{$\begin{array}{c}\text { Miejsce } \\
\text { w rankingu } \\
\text { Global } 2000\end{array}$} & \multirow[b]{2}{*}{ Company } & \multirow[b]{2}{*}{ Kraj } & \multirow[b]{2}{*}{ Rodzaj działalności } & \multicolumn{3}{|c|}{ Wartość sprzedaży } \\
\hline & & & & $\begin{array}{l}\text { w mld } \\
\text { USD }\end{array}$ & $\begin{array}{c}\text { miejsce } \\
\text { w rankingu } \\
\text { wg sprzedaży }\end{array}$ & $\begin{array}{c}\text { \% udział } \\
\text { w ogóle } \\
\text { badanych } \\
\text { korporacji }\end{array}$ \\
\hline 37 & IBM & USA & oprogramowanie i usługi & 98,8 & 2 & 4,9 \\
\hline 53 & Hewlett-Packard & USA & $\begin{array}{l}\text { technologie sprzętowe } \\
\text { i wyposażenie }\end{array}$ & 107,7 & 1 & 5,3 \\
\hline 59 & Samsung Electronics & Korea Płd. & półprzewodniki & 92,3 & 3 & 4,6 \\
\hline 63 & Microsoft & US & oprogramowanie i usługi & 57,9 & 10 & 2,9 \\
\hline 69 & Nokia & Finlandia & $\begin{array}{l}\text { technologie sprzętowe } \\
\text { i wyposażenie }\end{array}$ & 74,5 & 6 & 3,7 \\
\hline 90 & Cisco Systems & USA & $\begin{array}{l}\text { technologie sprzętowe } \\
\text { i wyposażenie }\end{array}$ & 37,7 & 16 & 1,9 \\
\hline 150 & Matsushita Electric Indl & Japan & $\begin{array}{l}\text { technologie sprzętowe } \\
\text { i wyposażenie }\end{array}$ & 77,5 & 5 & 3,8 \\
\hline 182 & Sony & Japan & $\begin{array}{l}\text { technologie sprzętowe } \\
\text { i wyposażenie }\end{array}$ & 70,6 & 7 & 3,5 \\
\hline 213 & Google & USA & oprogramowanie i usługi & 16,6 & 33 & 0,8 \\
\hline 511 & Hitachi & Japonia & $\begin{array}{l}\text { technologie sprzętowe } \\
\text { i wyposażenie }\end{array}$ & 87,2 & 4 & 4,3 \\
\hline 672 & Alcatel-Lucent & Francja & $\begin{array}{l}\text { technologie sprzętowe } \\
\text { i wyposażenie }\end{array}$ & 24,4 & 23 & 1,2 \\
\hline 1126 & Ingram Micro & USA & $\begin{array}{l}\text { technologie sprzętowe } \\
\text { i wyposażenie }\end{array}$ & 35,1 & 18 & 1,7 \\
\hline 1238 & Nortel Networks & Kanada & $\begin{array}{l}\text { technologie sprzętowe } \\
\text { i wyposażenie }\end{array}$ & 11,0 & 50 & 0,5 \\
\hline 1285 & Micron Technology & USA & półprzewodniki & 5,7 & 76 & 0,3 \\
\hline 1471 & Advanced Micro & USA & półprzewodniki & 6,0 & 70 & 0,3 \\
\hline 1505 & Thomson & Francja & $\begin{array}{l}\text { technologie sprzętowe } \\
\text { i wyposażenie }\end{array}$ & 7,7 & 60 & 0,4 \\
\hline 1540 & Tech Data & USA & $\begin{array}{l}\text { technologie sprzętowe } \\
\text { i wyposażenie }\end{array}$ & 23,4 & 24 & 1,2 \\
\hline 1717 & First Solar & USA & $\begin{array}{l}\text { technologie sprzętowe } \\
\text { i wyposażenie }\end{array}$ & 0,5 & 129 & 0,0 \\
\hline 1763 & Satyam Computer Services & Indie & oprogramowanie i usługi & 1,5 & 124 & 0,1 \\
\hline 1781 & Linear Technology & USA & półprzewodniki & 1,1 & 126 & 0,1 \\
\hline 1801 & Sanmina-SCI & USA & $\begin{array}{l}\text { technologie sprzętowe } \\
\text { i wyposażenie }\end{array}$ & 10,1 & 54 & 0,5 \\
\hline 1891 & Microchip Technology & USA & półprzewodniki & 1,0 & 127 & 0,1 \\
\hline 1905 & Tencent Holdings & Chiny & oprogramowanie i usługi & 0,4 & 130 & 0,0 \\
\hline 1931 & LogicaCMG & $\begin{array}{l}\text { Wlk. } \\
\text { Brytania }\end{array}$ & oprogramowanie i usługi & 6,1 & 69 & 0,3 \\
\hline 1944 & NHN & Korea Płd. & oprogramowanie i usługi & 0,7 & 128 & 0,0 \\
\hline
\end{tabular}

Źródło: opracowanie własne na podstawie The Global 2000 z 2008 r. 
informatycznych wg cech

\begin{tabular}{|c|c|c|c|c|c|c|c|c|}
\hline \multicolumn{3}{|c|}{ Wartość zysków/strat } & \multicolumn{3}{|c|}{ Wartość rynkowa } & \multicolumn{3}{|c|}{ Wartość aktywów } \\
\hline $\begin{array}{l}\text { w mld } \\
\text { USD }\end{array}$ & $\begin{array}{c}\text { miejsce } \\
\text { w rankingu } \\
\text { wg osiagganych } \\
\text { zysków/strat }\end{array}$ & $\begin{array}{l}\text { \% udział } \\
\text { w ogóle } \\
\text { badanych } \\
\text { korporacji }\end{array}$ & $\begin{array}{l}\text { w mld } \\
\text { USD }\end{array}$ & $\begin{array}{c}\text { miejsce } \\
\text { w rankingu } \\
\text { wg wartości } \\
\text { rynkowej }\end{array}$ & $\begin{array}{c}\text { \% udział } \\
\text { w ogóle } \\
\text { badanych } \\
\text { korporacji }\end{array}$ & $\begin{array}{l}\text { w mld } \\
\text { USD }\end{array}$ & $\begin{array}{c}\text { miejsce } \\
\text { w rankingu } \\
\text { wg wartości } \\
\text { aktywów }\end{array}$ & $\begin{array}{l}\text { \% udział } \\
\text { w ogóle } \\
\text { badanych } \\
\text { korporacji }\end{array}$ \\
\hline 10,4 & 3 & 6,8 & 157,6 & 2 & 5,1 & 120,4 & 1 & 5,7 \\
\hline 7,9 & 6 & 5,2 & 122,0 & 6 & 3,9 & 88,6 & 3 & 4,2 \\
\hline 8,6 & 4 & 5,6 & 87,8 & 10 & 2,8 & 87,5 & 5 & 4,2 \\
\hline 17,0 & 1 & 11,1 & 253,2 & 1 & 8,1 & 67,3 & 6 & 3,2 \\
\hline 10,5 & 2 & 6,9 & 145,7 & 4 & 4,7 & 52,6 & 10 & 2,5 \\
\hline 8,1 & 5 & 5,3 & 145,4 & 5 & 4,7 & 55,3 & 9 & 2,6 \\
\hline 1,9 & 20 & 1,2 & 45,3 & 18 & 1,5 & 65,9 & 7 & 3,1 \\
\hline 1,1 & 29 & 0,7 & 48,0 & 17 & 1,5 & 97,9 & 2 & 4,7 \\
\hline 4,2 & 10 & 2,8 & 147,7 & 3 & 4,7 & 25,3 & 22 & 1,2 \\
\hline$-0,3$ & 118 & $-0,2$ & 24,5 & 29 & 0,8 & 88,2 & 4 & 4,2 \\
\hline$-4,8$ & 130 & $-3,2$ & 13,8 & 47 & 0,4 & 48,0 & 12 & 2,3 \\
\hline 0,3 & 97 & 0,2 & 2,6 & 127 & 0,1 & 9,0 & 61 & 0,4 \\
\hline$-1,0$ & 127 & $-0,6$ & 3,8 & 118 & 0,1 & 17,1 & 35 & 0,8 \\
\hline$-0,7$ & 126 & $-0,5$ & 5,7 & 101 & 0,2 & 14,5 & 41 & 0,7 \\
\hline$-3,4$ & 129 & $-2,2$ & 4,4 & 114 & 0,1 & 11,6 & 50 & 0,5 \\
\hline 0,1 & 114 & 0,0 & 2,1 & 128 & 0,1 & 10,2 & 58 & 0,5 \\
\hline 0,1 & 110 & 0,1 & 1,9 & 129 & 0,1 & 5,2 & 87 & 0,2 \\
\hline 0,2 & 105 & 0,1 & 16,1 & 38 & 0,5 & 1,4 & 128 & 0,1 \\
\hline 0,3 & 93 & 0,2 & 7,3 & 84 & 0,2 & 1,6 & 126 & 0,1 \\
\hline 0,4 & 79 & 0,2 & 6,1 & 94 & 0,2 & 1,4 & 127 & 0,1 \\
\hline$-1,2$ & 128 & $-0,8$ & 0,9 & 130 & 0,0 & 4,7 & 91 & 0,2 \\
\hline 0,4 & 90 & 0,2 & 5,8 & 98 & 0,2 & 2,6 & 120 & 0,1 \\
\hline 0,1 & 108 & 0,1 & 11,4 & 59 & 0,4 & 0,6 & 130 & 0,0 \\
\hline 0,2 & 106 & 0,1 & 2,7 & 126 & 0,1 & 6,5 & 75 & 0,3 \\
\hline 0,2 & 107 & 0,1 & 10,9 & 64 & 0,3 & 0,6 & 129 & 0,0 \\
\hline
\end{tabular}


Wśród badanych firm aż 9 powstało przed rokiem 1900 (tj. 6,9\%), w latach 19011945 kolejnych $21(23,1 \%)$ ze 130 omawianych korporacji, a w następnych trzech dekadach (tj. w latach 1946-1975) zarejestrowano 27 korporacji informatycznych. Największy odsetek w grupie badanych firm stanowią korporacje powstałe w latach 1976-1985, w tym okresie zostało zarejestrowanych aż 37 (28,5\%) firm. W następnym dziesięcioleciu powstało 19 korporacji, w ostatnich zaś 10 latach otwarto 17 tego typu firm informatycznych.

Przyjęte do badań korporacje informatyczne odznaczają się dużym zróżnicowaniem potencjału ekonomicznego, który wyraża się wartością sprzedaży, zysków, aktywów oraz wartością rynkową.

Pierwszą pozycję pod względem wartości sprzedaży² zajmuje Hewlett-Packard, którego sprzedaż miała wartość 107,7 mld USD, drugą IBM, a trzecią Samsung Electronics (tab. 2). Na czwartej pozycji znajduje się Hitachi, na piątej Matsushita Electric Industrial. Łącznie korporacje te obejmują sprzedaż o wartości 463,4 mld USD, tj. 23,0\% sprzedaży 130 największych firm informatycznych (ryc. 1).

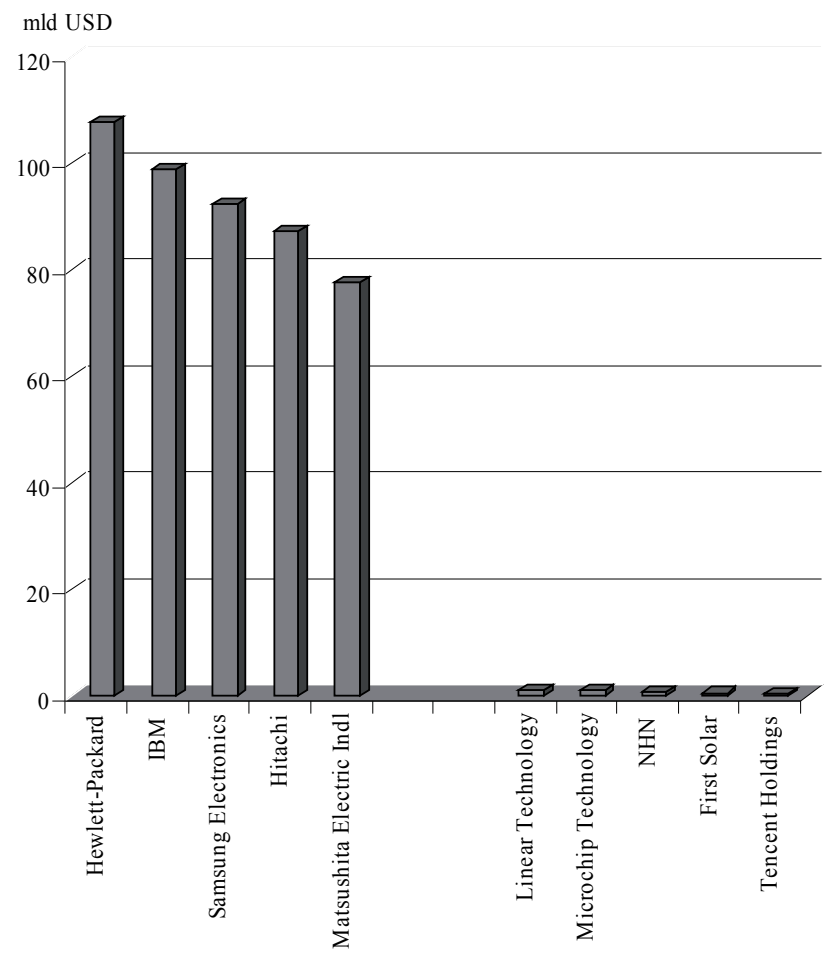

Ryc. 1. Zróżnicowanie wartości sprzedaży korporacji informatycznych w 2007 roku

Źródło: opracowanie własne na podstawie The Global 2000 z 2008 r.

${ }^{2}$ „Przychody ze sprzedaży to kwota uzyskana lub należna od odbiorcy z tytułu dokonanej sprzedaży składników aktywów jednostki oraz z tytułu świadczonych usług” (Nowak 2008, s. 117). W rankingu jako wartość sprzedaży traktowano wartość przychodu (revenue): ze sprzedaży, pozostałych przychodów operacyjnych oraz przychodów finansowych w przypadku firm podejmujących różne rodzaje działalności, np. w przypadku IBM, lub wartość sprzedaży netto (net sales), np. Nokia, w zależności od przedsiębiorstwa. Wartości zostały przeliczone na USD. 
Natomiast najniższymi wartościami sprzedaży spośród analizowanych korporacji charakteryzują się: Linear Technology, Microchip Technology, NHN, First Solar, Tencent Holdings, których wartość sprzedaży w 2007 roku oscylowała od 1,1 mld USD do $400 \mathrm{mln}$ USD, stanowiąc łącznie $0,2 \%$ ogółu sprzedaży.

W zakresie osiąganych zysków ${ }^{3}$ najwyższą pozycję zajął Microsoft, którego zysk wynosi 17,0 mld USD. Na drugim miejscu znajduje się Nokia, na trzecim IBM, a na kolejnych dwóch miejscach odpowiednio Samsung Electronics i Cisco Systems. W sumie korporacje te osiągnęły 54,5 mld USD zysków, co stanowi 35,8\% ogółu zysków analizowanych firm (ryc. 2).

Natomiast najwyższe straty w 2007 roku wśród korporacji informatycznych osiąnęła firma Alcatel-Lucent ( $-4,8$ mld USD), a nieco mniejsze: Advanced Micro, Sanmina-SCI, Nortel Networks, Micron Technology. W sumie korporacje osiągnęły straty w wysokości 11,0 mld USD.

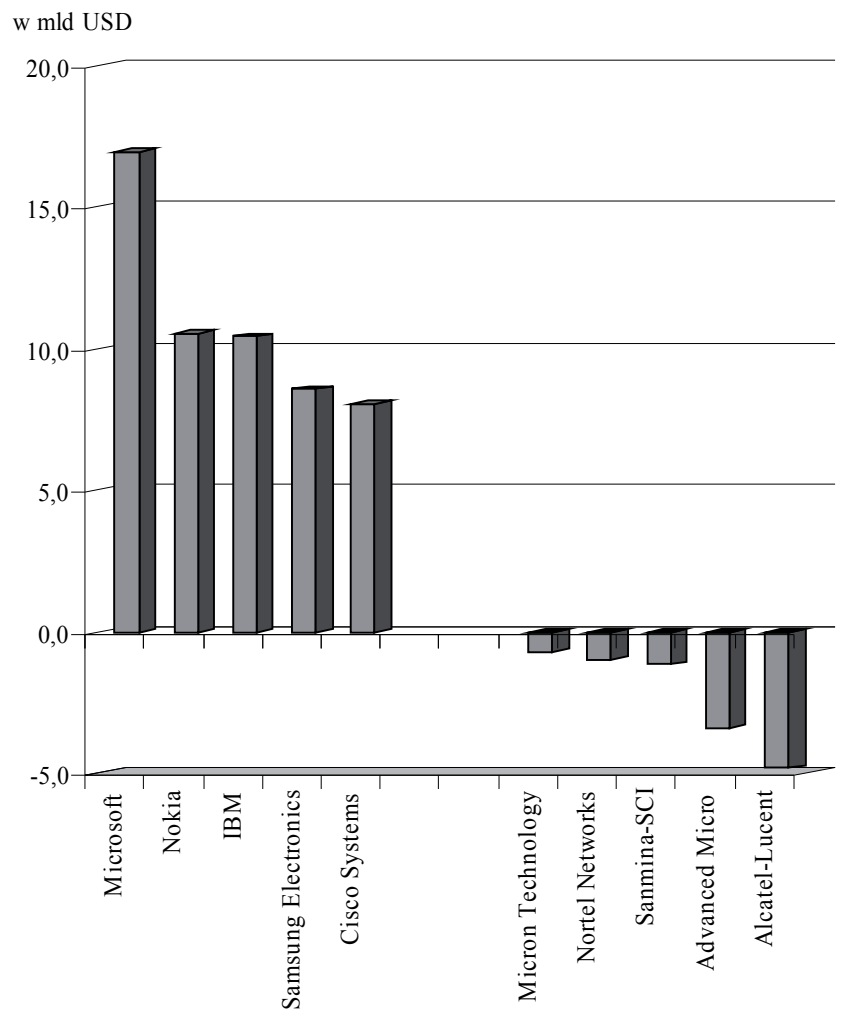

Ryc. 2. Zróżnicowanie wartości zysków i strat korporacji informatycznych w 2007 roku

Źródło: opracowanie własne na podstawie The Global 2000 z 2008 r.

${ }^{3}$,Zysk w kontekście działalności gospodarczej to dochód uzyskany po wytworzeniu, wprowadzeniu na rynek i sprzedaży towaru po poniesieniu wszelkich kosztów" (Munn i in. 1991, s. 837). Jako zyski (profits) w rankingu traktowano pozycję w sprawozdaniu finansowym firmy: net income (dochód netto) lub profit attributable to equity holders of the parent (zysk przypadający na akcjonariuszy jednostki dominującej), w zależności od tego, która wartość pojawiała się w sprawozdaniu. Wartości zostały przeliczone na USD. 
Również z punktu widzenia wartości rynkowej ${ }^{4}$ wśród analizowanych korporacji czołową pozycję zajął Microsoft, cechujący się wartością 253,2 mld USD. Drugą pozycję osiągnął wspomniany już IBM, a trzecią Google, następną Nokia i Cisco Systems. Razem wartość rynkowa tych korporacji obejmuje 849,48 mld USD, tj. 27,3\% wartości rynkowej przyjętych do badań firm (ryc. 3).

Najniższą wartością rynkową charakteryzowała się korporacja Sanmina-SCI, cechująca się wartością 0,9 mld USD $(0,03 \%$ w ogóle). Natomiast wartości rynkowe: Jabil Circuit, Tatung, LogicaCMG, Ingram Micro, Thomson, Tech Data wynosiły poniżej 3 mld USD, stanowiąc łącznie 0,5\% wartości rynkowej badanych korporacji.

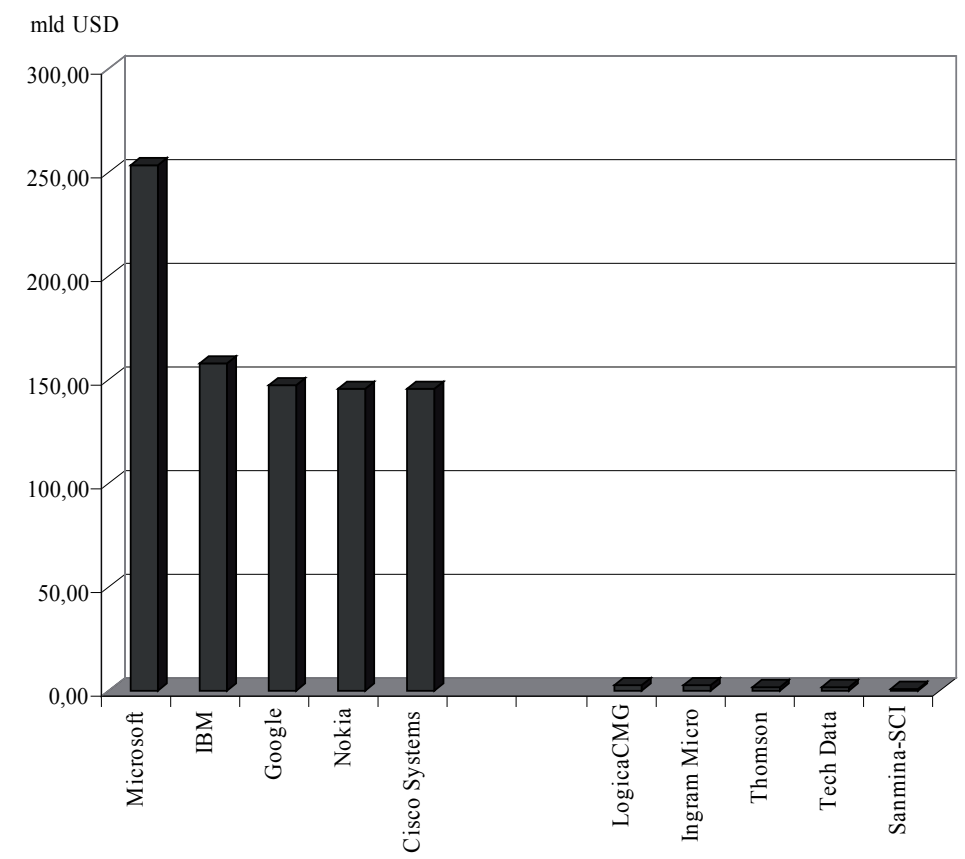

Ryc. 3. Zróżnicowanie wartości rynkowej korporacji informatycznych na dzień 29 lutego 2008

Źródło: opracowanie własne na podstawie The Global 2000 z 2008 r.

Rozpatrując wielkość aktywów ${ }^{5}$ posiadanych przez analizowane korporacje należy zauważyć, że najwyższe wartości cechują IBM (120,4 mld USD, co stanowi 5,7\% ogółu 130 korporacji), Sony (97,9 mld) oraz Hewlett-Packard (88,6 mld), Hitachi (88,2 mld USD) i Samsung Electronics (87,5 mld USD), których aktywa łącznie wynoszą 482,6 mld USD, czyli 23,0\% aktywów ogółu korporacji informatycznych (ryc. 4).

${ }^{4}$ Wartość rynkowa przedsiębiorstw obliczana jest na podstawie ceny akcji przedsiębiorstwa na dzień 29 lutego 2008. Wartości zostały przeliczone na USD.

${ }^{5}$ Aktywa (assets) to zasoby kontrolowane przez jednostkę powstałe w wyniku zdarzeń z przeszłości, z których według przewidywań jednostka osiągnie w przyszłości korzyści ekonomiczne (Międzynarodowe Standardy Sprawozdawczości Finansowej 2004, s. 68). Wartościom aktywów z rankingu odpowiadają wartości „wszystkich aktywów" (assets total) w sprawozdaniach finansowych poszczególnych firm. Wartości zostały przeliczone na USD. 
Natomiast najniższa wartość posiadanego majątku cechuje: Tencent Holdings, NHN, First Solar, Linear Technology oraz Satyam Computer Services, których aktywa łącznie wynoszą 5,6 mld USD, tj. 0,3\% ogółu aktywów analizowanych korporacji informatycznych.

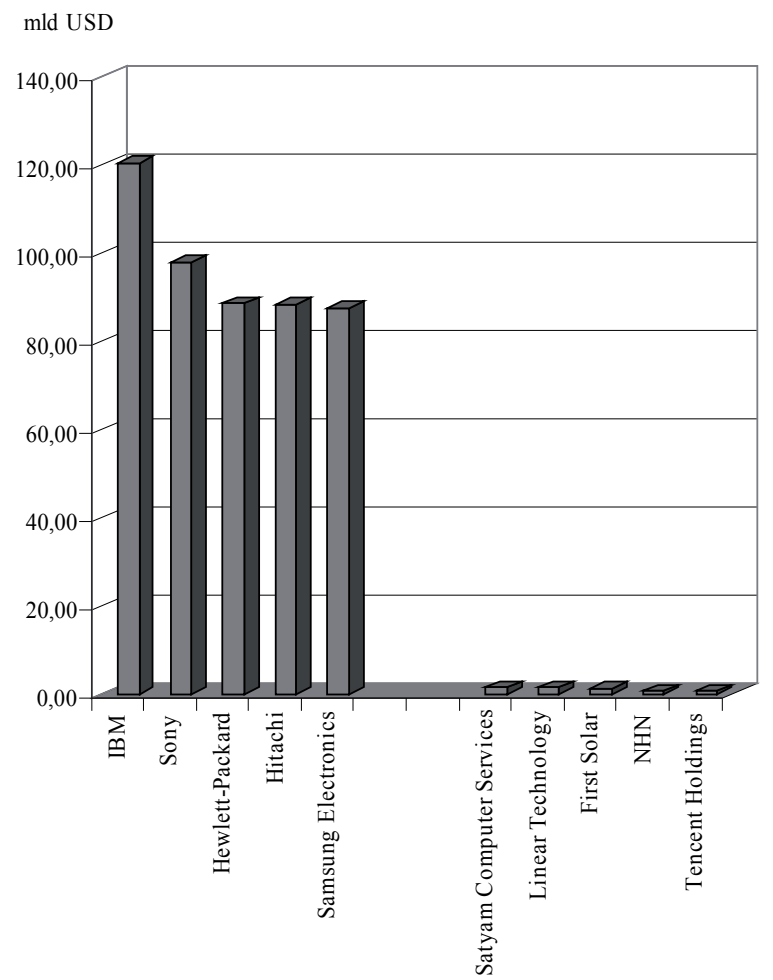

Ryc. 4. Zróżnicowanie wartości aktywów posiadanych przez korporacje informatyczne w 2007 roku Źródło: opracowanie własne na podstawie The Global 2000 z 2008 r.

Tab. 3. Korelacja występująca miedzy cechami korporacji informatycznych

\begin{tabular}{|l|c|c|c|c|}
\hline \multirow{2}{*}{} & \multicolumn{4}{|c|}{ wartość } \\
\cline { 2 - 5 } & sprzedaży & zysków i strat & aktywów & rynkowa \\
\hline wartość sprzedaży & 1,000 & 0,599 & 0,923 & 0,603 \\
\hline wartość zysków i strat & 0,599 & 1,000 & 0,618 & 0,913 \\
\hline wartość aktywów & 0,923 & 0,618 & 1,000 & 0,675 \\
\hline wartość rynkowa & 0,603 & 0,913 & 0,675 & 1,000 \\
\hline
\end{tabular}

Źródło: obliczenia własne na podstawie The Global 2000 z 2008 r.

Należy zaznaczyć, iż pomiędzy poszczególnymi cechami charakteryzującymi korporacje w zachodzi zróżnicowana korelacja (tab. 3). Przeciętna korelacja występuje między wartością sprzedaży a wartością zysków i wartością rynkową badanych korporacji, a także 
między wartością zysków a wartością aktywów. Wysoka korelacja występuje między wartością aktywów a wartością rynkową analizowanych firm. Natomiast bardzo wysoka zależność występuje między wartością zysków a wartością rynkową oraz wartością sprzedaży a wartością aktywów.

Tab. 4. Wartości miernika syntetycznego i jego struktura (wartość miernika $\geq 1$ )

\begin{tabular}{|c|c|c|c|c|c|}
\hline \multirow{3}{*}{ Lp. } & \multirow{3}{*}{ Korporacja } & \multirow{3}{*}{$\begin{array}{c}\text { Miernik } \\
\text { syntetyczny* }\end{array}$} & \multicolumn{3}{|c|}{ Struktura miernika syntetycznego } \\
\hline & & & \multicolumn{3}{|c|}{ udział \% wartości } \\
\hline & & & sprzedaży & aktywów & rynkowej \\
\hline 1. & IBM & 5,2 & 31,2 & 36,5 & 32,2 \\
\hline 2. & Microsoft & 4,7 & 20,2 & 22,6 & 57,2 \\
\hline 3. & Hewlett-Packard & 4,5 & 39,6 & 31,3 & 29,1 \\
\hline 4. & Samsung Electronics & 3,9 & 39,6 & 36,0 & 24,4 \\
\hline 5. & Nokia & 3,6 & 34,0 & 23,0 & 43,0 \\
\hline 6. & Sony & 3,2 & 36,1 & 48,0 & 15,9 \\
\hline 7. & Hitachi & 3,1 & 46,5 & 45,1 & 8,4 \\
\hline 8. & Cisco Systems & 3,1 & 20,4 & 28,7 & 50,9 \\
\hline 9. & Matsushita Electric Indl & 2,8 & 45,6 & 37,2 & 17,2 \\
\hline 10. & Intel & 2,8 & 23,0 & 32,1 & 44,9 \\
\hline 11. & Google & 2,3 & 12,2 & 17,8 & 70,0 \\
\hline 12. & Apple & 2,1 & 21,0 & 22,8 & 56,2 \\
\hline 13. & Toshiba & 2,0 & 49,1 & 37,9 & 13,0 \\
\hline 14. & Canon & 2,0 & 33,7 & 32,6 & 33,7 \\
\hline 15. & Oracle & 1,9 & 17,2 & 29,3 & 53,5 \\
\hline 16. & Dell & 1,9 & 52,5 & 22,7 & 24,8 \\
\hline 17. & LM Ericsson & 1,4 & 33,8 & 40,3 & 26,0 \\
\hline 18. & Fujitsu & 1,4 & 51,2 & 37,3 & 11,4 \\
\hline 19. & Motorola & 1,4 & 43,3 & 39,5 & 17,2 \\
\hline 20. & Hon Hai Precision Ind & 1,4 & 48,4 & 22,0 & 29,6 \\
\hline 21. & Alcatel-Lucent & 1,3 & 30,7 & 58,1 & 11,2 \\
\hline 22. & NEC & 1,2 & 53,1 & 39,1 & 7,8 \\
\hline 23. & Qualcomm & 1,2 & 13,1 & 24,8 & 62,2 \\
\hline 24. & Softbank & 1,1 & 31,2 & 48,8 & 20,1 \\
\hline 25. & SAP & 1,1 & 22,4 & 21,5 & 56,1 \\
\hline 26. & Sharp & 1,1 & 41,6 & 37,8 & 20,6 \\
\hline 27. & Nintendo & 1,0 & 13,0 & 20,1 & 66,9 \\
\hline 28. & Taiwan Semiconductor & 1,0 & 16,3 & 27,7 & 55,9 \\
\hline
\end{tabular}

* wg metody Z. Zioło (1972, 1973)

Źródło: obliczenia własne na podstawie The Global 2000 z 2008 r. 
Duży stopień zróżnicowania ekonomicznego korporacji informatycznych potwierdza miernik syntetyczny potencjału ekonomicznego, obliczony w oparciu o omawiane wcześniej mierniki (wartość sprzedaży, aktywów, wartość rynkowa). Najwyższe wartości miernika osiagają: IBM, Microsoft, Hewlett-Packard, Samsung Electronics i Nokia (tab. 4). Analiza struktury miernika syntetycznego pozwala stwierdzić, że w korporacjach Dell, Fujitsu i NEC dominujący jest udział wartości sprzedaży (ponad 50\%), w Alcatel-Lucent i Sony potencjał ekonomiczny uzależniony jest od wartości posiadanych aktywów, natomiast w korporacji Google, Nintendo, Qualcomm, Microsoft, Apple, SAP, Cisco Systems, Oracle i Taiwan Semiconductor potencjał uzależniony jest od ich wartości rynkowej. W pozostałych korporacjach w zbliżony sposób na potencjał firmy wpływają poszczególne cechy.

W świetle przedstawionej analizy zaznacza się różny stopień zróżnicowania analizowanych firm (tab. 5). Rozpiętość średnich poszczególnych cech waha się od 24,0 do 1,2 mld USD. Średnia wartość zysków była dwadzieścia razy większa niż średnia wartość rynkowa korporacji. Natomiast średnia wartość sprzedaży była zbliżona do średniej wartości aktywów.

Tab. 5. Stopień zróżnicowania potencjału ekonomicznego korporacji informatycznych

\begin{tabular}{|l|c|c|c|}
\hline \multicolumn{1}{|c|}{ Cechy } & $\begin{array}{c}\text { średnia } \\
\text { arytmetyczna* }\end{array}$ & $\begin{array}{c}\text { odchylenie } \\
\text { standardowe* }\end{array}$ & $\begin{array}{c}\text { współczynnik } \\
\text { zmienności w \% }\end{array}$ \\
\hline wartość sprzedaży & 15,5 & 21,2 & 137,0 \\
\hline wartość zysków i strat & 1,2 & 2,5 & 213,1 \\
\hline wartość aktywów & 16,2 & 21,2 & 131,0 \\
\hline wartość rynkowa & 24,0 & 37,9 & 158,1 \\
\hline
\end{tabular}

*w mld USD.

Źródło: obliczenia własne na podstawie The Global 2000 z 2008 r.

O dużej zmienności świadczą również wartości odchylenia standardowego, które ma identyczną wartość dla wartości sprzedaży i wartości aktywów wynoszące 21,2 mld USD, zupełnie rozbieżne zaś dla wartości zysków (2,5 mld USD) i dla wartości rynkowej (37,9 mld USD).

Wysoki stopień zróżnicowania potencjału ekonomicznego firm informatycznych podkreślają bardzo wysokie wartości współczynnika zmienności dla poszczególnych cech. Wahają się one od 213,1\% dla wartości zysków i strat osiaganych przez korporacje, przez $158,1 \%$ dla wartości rynkowej, $137,0 \%$ dla wartości sprzedaży, po $131,0 \%$ dla wartości posiadanego majątku (ryc. 5).

W świetle przedstawionej analizy można przyjąć, że korporacje informatyczne wykazują duże zróżnicowanie w zakresie posiadanego potencjału ekonomicznego. Największe korporacje, o ugruntowanej pozycji na rynku, np. Microsoft, IBM czy Hewlett-Packard, mają szczególne znaczenie również ze względu na to, że ich wyniki działalności są wzorem dla innych firm. 


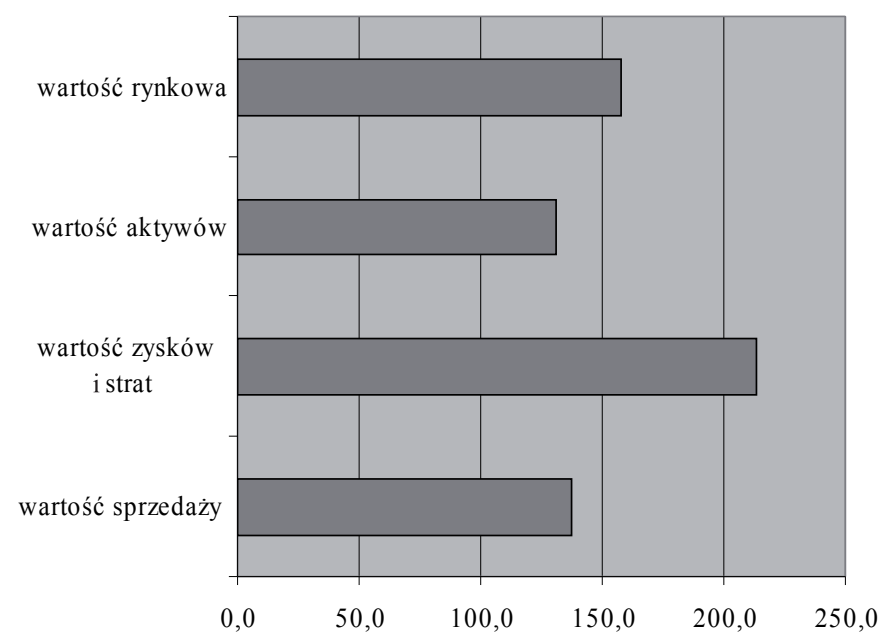

Ryc. 5. Zróżnicowanie współczynnika zmienności dla wybranych cech

Źródło: opracowanie własne na podstawie The Global 2000 z 2008 r.

\section{Literatura}

Kilar W., 2009, Koncentracja przestrzenna światowych firm informatycznych, [w:] Wpływ procesów globalizacji i integracji europejskiej na transformacje struktur przemysłowych, red. Z. Zioło i T. Rachwał, Prace Komisji Geografii Przemysłu PTG nr 12, Komisja Geografii Przemysłu PTG i IG AP w Krakowie, Warszawa-Kraków, s. 97-108.

The Global 2000 [w:] http://www.forbes.com/2008/04/02/worlds-largest-companies-biz-2000global 08-cx_sd_0402global_land.html.

Międzynarodowe Standardy Sprawozdawczości Finansowej (MSSF), 2004, International Accounting Standard Bard, Londyn, Stowarzyszenie Księgowych w Polsce, Warszawa.

Munn G. G., Garcia F. L., Woelfel Ch. J., 1991, Encyclopedia of Banking \& Finance, McGraw-Hill Book Company, London.

Nowak E., 2008, Analiza sprawozdań finansowych, PWE, Warszawa.

Opałło M., 1972, Mierniki rozwoju regionów, PWE, Warszawa.

Sierpińska M., Jachna T., 2004, Ocena przedsiębiorstw wedlug standardów światowych, WN PWN, Warszawa.

Turyna J., 2006, Standardy sprawozdawczości finansowej. Vademecum rachunkowości, Difin, Warszawa.

Zioło Z., 1972, Próba konstrukcji miernika syntetycznego w zastosowaniu do badań przemystu, Komisja Nauk Geograficznych, Sprawozdania z posiedzeń Komisji Naukowych PAN Oddział w Krakowie, t. XV/1, Kraków, s. 191-194.

Zioło Z., 1973, Analiza struktury przestrzennej i form koncentracji przemystu województwa rzeszowskiego w świetle wybranych mierników, Folia Geographica, Series: Geographica-Oeconomica, Polska Akademia Nauk, Oddział w Krakowie, vol. VI, Kraków, s. 95-116.

Zioło Z., 2004, Kształtowanie sięfirm informatycznych jako nowych elementów struktury przestrzennej przemystu, [w:] Przemiany struktur przemysłowych, red. Z. Zioło, Z. Makieła, Prace Komisji 
Geografii Przemysłu PTG nr 7, Komisja Geografii Przemysłu PTG w Warszawie, i IG AP w Krakowie, Warszawa-Kraków, s. 97-106.

Zioło Z., 2006, Zróżnicowanie światowej przestrzeni przemysłowej w świetle siedzib zarzq̨ów wiodacych korporacji, [w:] Międzynarodowe uwarunkowania rozwoju polskiego przemystu, red. Z. Zioło, T. Rachwał, Prace Komisji Geografii Przemysłu PTG, nr 8, Komisja Geografii Przemysłu PTG w Warszawie, IG AP w Krakowie, Warszawa-Kraków, s. 9-26.

Zioło Z., 2009, Procesy ksztaltowania się światowych korporacji i ich wptyw na otoczenie, [w:] Wptyw procesów globalizacji i integracji europejskiej na transformację struktur przemystowych, red. Z. Zioło i T. Rachwał, Prace Komisji Geografii Przemysłu PTG, nr 12, Komisja Geografii Przemysłu PTG w Warszawie i IG AP w Krakowie, Warszawa-Kraków.

Zorska A., 2007, Korporacje transnarodowe. Przemiany, oddziatywania, wyzwania, PWE, Warszawa.

\section{Diversification of the economic potential of global IT Corporations}

Supranational corporations have an impact on organizing the world's economic, social, and cultural space by means of systems of network and production connections. Among 2000 top world corporations presented in The Global 2000 ranking dated 2008, published by Forbes, 130 corporations representing $6.5 \%$ of the total of corporations featured in the ranking.

This study contains an analysis of economic potential of the largest world IT corporations. It aims to find a definition of their diversification from the point of view of their potential, in the light of many features and the relationships between them, and to determine their ranking in the synthetic measure.

In 2007, IT corporations in question generated the total of 2015.3 billion USD in sales, which represents a $6.8 \%$ share in total sales volume of 2000 corporations presented in the ranking, generating the profit of 152.4 billion USD, which constitutes a $6.5 \%$ share in total profits; however, the value of their assets reached 2100.4 billion USD, which represents just $1.8 \%$ of all corporations' assets, while the market value of corporations studied is 3115 billion USD, representing $8.1 \%$ of the market value of 2000 top world corporations.

As preliminary research shows, high concentration of IT corporations is visible, which leads to a related diversification of the world space.

mgr Wioletta Kilar

Uniwersytet Pedagogiczny im. Komisji Edukacji Narodowej w Krakowie

Instytut Geografii

Zakład Przedsiębiorczości i Gospodarki Przestrzennej

e-mail:W.Kilar@up.krakow.pl 